\title{
Interventions for Causes Avoidable and Sensitive to Primary Care
}

\author{
João Antônio Leal de Miranda ${ }^{1}$, Amanda Alves Feitosa ${ }^{2}$ and Luciene Ferreira de Lima ${ }^{1 *}$ \\ ${ }^{1}$ College professor of Universidade Regional do Cariri- Campus São Miguel, Direito, Brazil \\ ${ }^{2}$ Graduation student of Universidade Regional do Cariri- Campus São Miguel, Direito, Brazil
}

Submission: February 10, 2017; Published: February 16, 2017

*Corresponding author: Luciene Ferreira de Lima, College professor of Universidade Regional do Cariri- Campus São Miguel, Direito, Crato, CE, Brazil, Email: luciene_de_lima@outlook.com

\begin{abstract}
The Unified Health System (SUS) is developed with care divided into aspects of care, so it provides a comprehensive service to the users, where basic attention (BA) is perceived as a gateway to non-SUS care. However, in their country that not always a BA provide an effective assistance, triggering innumerable hospitalizations that would be liable to solubility in the $\mathrm{AB}$, causing injury in the health of users and high expenses of the SUS. According to reports, the highest rates of hospitalizations are as follows: pneumonia, gastroenteritis, diabetes mellitus and systemic arterial hypertension, where all diseases are treated with BA. It is concluded that there is a high rate of hospitalizations avoidable by BA.
\end{abstract}

Keywords: Primary health care; Hospitalization; Health profile; Assistance

Abbreviations: BA: Basic Attention; FHTs: Family Health Teams; PHC: Primary Health Care; SUS: Unique Health System; ICU: Intensive Treatment Unit; IBGE: Brazilian Institute of Geography and statistics; ICSAP: Conditions that are Possible for Primary Health Care; SHA: Systemic Arterial Hypertension; DM: Diabetes Mellitus

\section{Introduction}

The Brazilian public health system is organized into care networks, whose actions and health services are distributed by levels of technological complexity. At the outset, primary health care (PHC) is the first level of health care and its access is provided by the Family Health Teams (FHTs) [1,2], and later, we have a hospital network, which in turn performs a lot of procedures of medium and high complexity, with the important expenses in the Unified Health System - SUS [3].

The SUS evidences the primary health care being responsible for actions of prevention, health promotion, treatment and rehabilitation of a certain group of users, being the entrance door of these in the health services, that is, the PHS associates with the a group of diagnoses whose hospitalizations are avoidable in the midst of appropriate health care [4-6].

Studies evidenced that the early treatment of acute health alterations, together with the control and follow-up of chronic pathologies, has a repercussion on the reduction of hospital admissions. Where high rates of avoidable hospital admissions with interventions in basic care show the deficiency, difficulty in accessing the health system or its low resolution, implying the need to investigate the cause of this fact, being considered an important indicator for the analysis of the effectiveness of attention basic, in such a way to assess users, health professionals and managers [7].

It is known that about 80 to $90 \%$ of health problems could be solved at the primary level, or prevented at the first level of health care. Primary health care, through the adoption of health promotion, could reduce the occurrence of severe cases of illness and, consequently, decrease the demand for hospital admissions, more complex treatments and costs for the Unified Health System (SUS) [8].

Data from the IBGE, in 2002, showed the health facilities with an inpatient service with growth of about $1.28 \%$ per year between 1976 and 2002, reaching a total of 7,397 units [9]. The costs of ICUs have caused concern in several countries, since they are units that consume many resources and generate many costs. In Brazil, the cost of an average daily rate is approximately $\mathrm{R} \$ 1$ thousand, which can reach $\mathrm{R} \$ 25$ thousand [10]. Thus, 
expenditures on services of medium and high complexity have increased drastically, mainly due to hospitalizations due to conditions sensitive to primary health care (ICSAP).

The high frequency of hospitalization for diseases considered easy to prevent and amenable to diagnosis and treatment are associated with deficits in the extent of coverage and may reflect both the inadequacy of care for certain population groups and their living and health conditions [2,6]. In addition, such health costs threaten the financial sustainability of many health care systems only [11], which makes it necessary strategies and measures to minimize costs [10].

In this way, it can be seen that basic care must be decisive and comprehensive, being used as a gateway to services, so that entry to levels of medium and high complexity should only exist in cases that have exceeded their responsibility [1]. Therefore, it is necessary to analyze the referrals for medium and high complexity services, in order not to overload the services and to promote the rationing of resources at each level of complexity, in an attempt to avoid undue hospitalization [6].

Governments and researchers have increased interest in identifying ineffective and unnecessary health care. Avoidable hospitalizations, also reported as hospitalizations for conditions sensitive to outpatient care, are among the targets of studies in countries such as the United States, Canada and Brazil [11]. Reducing the number of preventable hospitalizations offers opportunities for reducing health spending and improving the quality of care and quality of life [12].

The high rate of preventable hospital admissions is related to the quality of the services provided in the PHC, where the goal and greatest challenge of the FHTs is precisely to guarantee a quantitative expansion, in order to offer quality assistance, in order to positively impact In the ICSAP.

In order to meet one of the doctrinal principles of SUS universality - it is necessary to plan an effective basic care, however, this fact must be intertwined with all health systems in a structured way, so that a comprehensive and continuous care can be performed of quality [13].

The high index of hospitalizations due to treatable diseases at basic care level, such as pneumonia, gastroenteritis, dengue, hypertension, DM, shows the difficulties of access and quality in PHC, we know that the high hospitalization rates are a reflection of poor PHC. Due to these services are considered the most adequate to take on the role of coordinating the therapeutic path in most of the individual's illness processes; however, socioeconomic factors, environmental, cultural, resource scarcity and structure interfere in this scenario $[13,14]$.

In Brazil, the Family Health Strategies emphasize health care networks and function as a structuring axis of reorganization, since they consider the decentralization and hierarchization of the actions provided, where they are characterized as the services that best fit the coordinating function the therapeutic path of the user in most episodes of illness.

Since PHC aims to provide quality, completeness, and effectiveness in the assistance provided to the user, having as a facilitator in this process the performance under the territory and the organized offer of services, in interventions for prevention and health promotion, The most complex and diverse aspects of the epidemiological situation in Brazil [13].

\section{Conclusion}

In view of the foregoing, it can be seen that there is a failure in the primary care actions, this can be observed due to the high number of hospitalizations that are considered treatable in the primary health level, emphasizing as more common pneumonia, gastroenteritis, SAH and DM, Where all the actions of the APS are considered sensitive. It is noticed the failure of specific policies in order to promote their restructuring, so that they meet the real need of SUS users in an integrated and decentralized manner.

\section{References}

1. Oliveira BRG, Viera CSV, Collet N, Lima RAG (2010) Causes of hospitalization in the National Healthcare System of children aged zero to four in Brazil. Rev Bras Epidemiol 13(2): 1-9.

2. Mendonça SS, Albuquerque EC (2014) Perfil das internações por condições sensíveis à atenção primária em Pernambuco, 2008 a 2012. Epidemiol Serv Saúde 23(3): 463-474.

3. MENDES A (2014) O fundo público e os impasses do financiamento da saúde universal brasileira. Saúde Soc São Paulo 23(4): 1183-1197.

4. Brasil (2011) PORTARIA, №. 2.488, DE 21 DE OUTUBRO DE 2011. Aprova a Política Nacional de Atenção Básica, estabelecendo a revisão de diretrizes e normas para a organização da Atenção Básica, para a Estratégia Saúde da Família (ESF) e o Programa de Agentes Comunitários de Saúde (PACS).

5. Lavras C (2011) Atenção Primária à Saúde e a Organização de Redes Regionais de Atenção à Saúde no Brasil. Saúde Soc 20(4): 867-874.

6. Farnese JM, Sá MB, Rossi Barbosa LAR, Hoffmann EJ (2015) Perfil de morbidade hospitalar de pacientes pediátricos de 5 a 9 anos por causas sensíveis à atenção primária à saúde nas cinco principais capitais brasileiras. Revista Eletrônica Gestão \& Saúde 2: 1495-1496.

7. AlfradiqueME, Bonolo PF, Dourado I, Lima-costa MF, Macinko J, et al. (2009) Internações por condições sensíveis à atenção primária: a construção da lista brasileira como ferramenta para medir o desempenho do sistema de saúde (Projeto ICSAP - Brasil). Cad Saúde Pública 25(6): 1337-1349.

8. Lima CCA (2012) Internações hospitalares de crianças por condições sensíveis a atenção primária à saúde: estudo de tendência temporal de Pernambuco. Mestrado em saúde coletiva.

9. López EM (2004) Uma revisão do papel dos hospitais de pequeno porte no sistema único de saúde (sus) Dissertação apresentada como requisito parcial para a obtenção de título de Mestre em Gestão de Sistemas e Serviços da Saúde, do Programa de Mestrado Profissional da Escola Nacional de Saúde Pública da Fundação Oswaldo Cruz/ Ministério da Saúde. Brasília Junho de.

10. Silva MPP, Carvalho NZ, Pires JO (2013) Causas evitáveis de internamento em unidade de terapia intensiva. Iniciação Científica CESUMAR 15(2): 147-155.

11. Berlin C, Busato A, Rosemann T, Djalali S, Maessen M, et al. (2014) 
Avoidable hospitalizations in Switzerland: a small area analysis on regional variation, density of physicians, hospital supply and rurality. BMC Health Services Research 14: 289.

12. Freund T, Campbell SM, Geissler S, Kunz CU, Mahler C, et al. (2013) Strategies for Reducing Potentially Avoidable Hospitalizations for Ambulatory Care Sensitive Conditions. Annals of family medicine 11(4): 363-370.
13. Barreto J, Nery IS, Costa MSC (2012) Estratégia Saúde da Família e internações hospitalares em menores de 5 anos no Piauí, Brasil. Cad Saúde Pública 28(3).

14. Almeida PF, Giovanella L, Mendonça MHM, Escorel S (2010) Desafios à coordenação dos cuidados em saúde: estratégias de integração entre níveis assistenciais em grandes centros urbanos. Cad Saúde Pública 26(2).

\section{Your next submission with Juniper Publishers} will reach you the below assets

- Quality Editorial service

- Swift Peer Review

- Reprints availability

- E-prints Service

- Manuscript Podcast for convenient understanding

- Global attainment for your research

- Manuscript accessibility in different formats ( Pdf, E-pub, Full Text, Audio)

- Unceasing customer service

Track the below URL for one-step submission https://juniperpublishers.com/online-submission.php 